DOI https://doi.org/10.18551/rjoas.2018-08.28

\title{
EFFECT OF PERCEIVED EASE TO USE AND PERCEIVED USEFULLNESS TO THE USE OF E-BUDGETING SYSTEM IN THE REGIONAL GOVERNMENT
}

\author{
Arif Sesilia Adriana \\ Researcher, Indonesia \\ E-mail: sheyseil83@gmail.com
}

\begin{abstract}
Budget is basic needs in the administration of government activity. Implementation of EBudgeting supports transparency in the preparation of planning, discussion, managerial and supervision of the local budget through the facilities of information technology. The purpose of this research is to see behavioral aspects Apparatus Civil State in the implementation of E-Budgeting in the Regional Government of East Java Provincial Government to use models Acceptance Model, which will assess the level of influence of Perceived Ease to Use and Perceived usefulness to the use of E-Budgeting. Questionnaires were distributed to 40 State Civil Apparatus which has duties and functions related to the use of E-Budgeting. The results of this study indicate that the Perceived Ease to Use no effect on the use of E-Budgeting, Perceived usefulness effect on the use of E-Budgeting.
\end{abstract}

\section{KEY WORDS}

Budgeting, acceptance model, government, civil apparatus.

Budget is basic needs in the administration of government activity. Budget in public sector is an instrument of accountability in the management public funds and the implementation of programs financed from the budget. According Mardiasmo (2007) some of the reasons for the importance of public sector budgets are: a. Budgeting is a tool for the government to direct the socio-economic development, ensure sustainability, and improving quality of life. b. Budget necessary because of the problem of limited resources and options. c. Budget is required to assure that the government was accountable to the people. Therefore, local governments are expected to make efforts to repair the budget process and encourage the involvement of civil society more broadly, so that more enclosed spaces began to open to the public.

Until now, budgeting was considered as the process is quite complicated in the body of public sector organizations that are caused among which schedules budget preparation time, the unit price shopping items are not standard, recaps budgets per account shopping is not real time, the difficulty in controlling the process of follow-up and evaluation of budget by local Government Budget team, included within the scope of local government (https://ebudgeting.surabaya.go.id). On the other hand the budget system in the public sector on the public sector budget should be informed to the public as a form of accountability and transparency of government and provide space for people to actively assess the government's performance in public budgeting.

It is this factor that encourages the transparency of local budgets to the community, one way to budget transparency through the application of electronic data better known as E-Budgeting. Application of E-Budgeting supports transparency in the preparation of planning, discussion, management and control of the budget through information technology facilities. The importance of local government transparency and accountability of the budget in the era of regional autonomy can be viewed in two ways, namely as one form of government accountable to the people related to the allocation of funds from the taxes of the people and efforts to improve the management and good governance and reduce the chance of collusion, corruption and nepotism.

The purpose of research is to see the behavioral aspects of civil apparatus of the state in the implementation of E-Budgeting Local Government within the Government of East Java 
Province using the Acceptance Model (TAM), which will assess the level of influence of Perceived Ease to Use and Perceived usefulness to the use of E-Budgeting.

Practical benefits of this research can be input and a recommendation to the stakeholders especially the East Java provincial government in refining and improving the EBudgeting in connection with an embodiment of accountability and transparency as public disclosure so as to provide ease of public services in the realization of good governance.

\section{LITERATURE REVIEW}

E-government is System Information and Communication Technology (ICT) is owned or operated by the government that change the relationship with the community, the private sector or government agencies another way to increase community empowerment, improve service, strengthen accountability, improve transparency, or improve government efficiency (World Bank, 2001).

E-Budgeting is one form of e-government applications in the areas of the budget. Ebudgeting can be interpreted as financial data information through technology to help improve government openness (https://ebudgeting.surabaya.go.id). Where this system involves the management of public money (public money) are conducted in a transparent, efficient, rational and equitable included in this sense is a fair gender in order to create public accountability (public accountability). While the budget reform (budgeting reform) itself includes the process of preparation, approval, implementation and accountability of the budget.

Technology Acceptance Model (TAM) Some models are built to analyze and understand the factors that affect the acceptance of the use of computer technology, which were recorded in the literature and reference research results in the field of information technology is like the Theory of Reasoned Action (TRA), Theory of Planned Behavior (TPB), and the Technology Acceptance Model (TAM) TAM Model developed by Davis FD (1989) is one of the most widely used models in IT research. Information technology (IT) will affect its position in the acceptance of these technologies. One of the factors that can influence is the user's perception of the usefulness and ease of use of IT as an act that is reasonable in the context of technology.

TAM model developed from psychological theory, explains the behavior of computer users that is based on trust (belief), attitude (attitude), desire (intention) and the relationship of user behavior (user behavior relationship). The purpose of this model to explain the major factors of user behavior on user acceptance of the technology. TAM consists of two constructions, namely the perceived ease of use (perceived ease of use) and perceived benefits (perceived usefulness), which determines the intention of behavior (behavioral intention) a person to use a technology. Behavior intention is a measure of how much a person's desire to perform a certain action (D F. Davis, 1989). This model is more clearly illustrates that the acceptance of the use of IT is influenced by the usefulness and ease of use. Both have a high determinants and validity have been tested empirically. TAM model developed by Davis. F. D (1989) also got an extension of researchers like lqbaria (1994).

Several previous studies about the factors that influence public transparency include information on budgeting, especially in developing countries where the level of public confidence in the management of the budget is still low, an analysis of the impact of the use of information technology in budgeting also gives good results and increase public confidence

The perception of the ease of use of a technology is defined as a measure in which a person believes that the computer can be easily understood and used (Davis, F. D, 1989). According to the intensity of use and interaction between user and the system can also show the ease of use. The system is used more often indicate that the system is better known, is easier to operate and easier to use by users. Based on the above definition can be concluded that the ease of use will reduce the effort (both time and energy) someone in studying computer. The ease of comparison indicate that the people who use IT to work 
more easily than those who worked without the use of IT (manually). IT users believed that IT is more flexible,

According to Venkatesh and Morris (2003), perceived ease can be defined as the level of trust people that use a technology would be free of effort. This illustrates that individuals would prefer to interact with new technologies if they perceive that their cognitive effort relatively small. Perceived ease the process of hope (expectancy) and the perception of the benefit is the result of expectancy. So the perception of benefit is expected to be influenced by perceived ease because the easier a technology is used, the more useful the technology.

Perception of expediency is defined as a measure of where the use of a trustworthy technology will bring benefits to those who use it (Davis, 1989). Usefulness as a level where a person believes that the use of a particular subject will be able to improve the work performance of the person. Based on these definitions mean that the expediency of the use of computers can improve performance, work performance of people who use it. According to Thompson, et. al (1992) IT benefit is a benefit expected by IT users in performing their duties. It also says that people will use IT if you know the positive benefits of its use.

The use of information technology is strongly influenced by the ease of use and the benefits of information technology, if someone is already getting the benefits and convenience of information technology, which is in line with the perception about the ease of use of a technology is defined as a measure in which a person believes that the computer can be easily understood and used (Davis, 1989) and empirical studies demonstrate the positive impact the perceived ease of using technology on the intention to use these technologies (Palupi \& Tjahjono, 2008). Similarly, the research conducted by Venkatesh and Morris 2003) with a focus on the use of new technologies in the workplace, found that perceived ease significantly influence the perception variable expediency and behavior intention to use, Based on these studies it can be concluded that the use of a technology can be easily understood and used by such person, in order to get the first hypothesis, namely:

$\mathrm{H} 1$ = Perceived ease of positive and significant impact on the use of E-Budgeting.

The use of IT is based on the benefit obtained can predispose a person to accept or refuse to use the TI. Perception of expediency is defined as a measure of where the use of a trustworthy technology will bring benefits to those who use it (Davis, 1989). Usefulness as a level where a person believes that the use of a specific subject will increase the person's work performance). Those who perceive beneficial technology will encourage behavior using these technologies. In some of the above definition can be concluded that the use of a technology can bring benefits to the people who use them and the positive effect on the people who use them in carrying out his work in order to get the second hypothesis, namely:

$\mathrm{H} 2=$ Perceived benefits of positive and significant impact on the use of E-Budgeting.

Based on previous research and the formulation of hypotheses above, the obtained relationship variables in the image below:

\section{METHODS OF RESEARCH}

Data in this study are primary data through data collection techniques by spreading questionnaires to the respondents, the state civil officials in the Provincial Government of East Java in this case as the E-Budgeting as many as 40 people. The questionnaire in this study consisted of three parts: Perceived Ease to Use, Perceived Usefulness and Use EBudgeting System questionnaire on research using Likert scale of $1 \mathrm{~s} / \mathrm{d} 5$.

The dependent variable in this study is the use of E-Budgeting System $(Y)$ and not the dependent variable that is Perceived Ease to use (x1) and the Perceived usefulness (x2). These variables will be presented as follows:

1. Perceived Ease to use. Perception ease of use (Perceived Ease to use) is used to measure the level of ease of use E-Budgeting according to its users. This variable is measured with 9 questions with 5 Likert scale from strongly disagree to strongly agree. Measurement for this variable is the higher value indicates more easily perceived by the user. 
2. Perceived usefulness. Perception uses intended in this research is the user perception of the usefulness of the system E-Budgeting. This variable was measured with 6 questions with 5 Likert scale from strongly disagree to strongly agree. Measurement for this variable is the higher value shows the benefits generated by the system E-Budgeting higher as perceived by user.

3. The use of E-Budgeting System. Use of System in this study is the level of user interest to E-Budgeting in the implementation of the budgeting process in the preparation of the Regional Budget (APBD). Indicators for variable use of this system consists of 10 items of questions with 5 Likert scale ranging from strongly disagree to strongly agree with the measurements for this variable is the higher value showed interest in the system being used increasingly high as perceived by the wearer.

Measurement variable quality system and quality of information in this study were adopted from the questionnaire used by Davis (1989), but not all items are taken as an instrument to question the reason these items are not in accordance with the object of research,

This research is a quantitative research model analysis techniques multiple linear regression using SPSS (Statistical Product and Service Solutions). Analysis of the data in this study begins first with test validation and reliability. Test validation and reliability testing to test instrument that uses a Likert scale of 1-5.

\section{RESULTS OF STUDY}

Validity and Reliability Test Results Questionnaire. Testing research instruments in terms of both its validity and reliability of the 40respondents found that the results of the research instruments used are valid where the probability for the correlation value is less than 0.5 and a coefficient of reliability (Cronbach Alpha) greater than 0.6. More details can be seen in the following table:

Table 1 - Validity and Reliability Variables Perceived Ease to Use (X1)

\begin{tabular}{|c|c|c|c|c|}
\hline \multirow{2}{*}{ Group } & \multirow{2}{*}{ Item number } & \multicolumn{2}{|c|}{ validity } & Coefficient \\
\cline { 3 - 4 } & & Correlation $(\mathrm{r})$ & Plpha \\
\hline $\mathrm{X} 1$ & $\mathrm{X} 1.1$ & 0880 & 0000 & \\
& $\mathrm{X} 1.2$ & 0832 & 0000 & \multirow{2}{*}{0951} \\
\hline & $\mathrm{X} 1.3$ & 0888 & 0000 \\
\hline & $\mathrm{X} 1.4$ & 0922 & 0000 & 0000 \\
\hline & $\mathrm{X} 1.5$ & 0938 & 0000 & 0000 \\
\hline & $\mathrm{X} 1.6$ & 0586 & 0000 & \\
\hline & $\mathrm{X} 1.7$ & 0753 & 0000 & \\
\hline
\end{tabular}

Based on data from the above table shows all the items of questions for variables Perceived Ease has a probability value less than 0.05 and has a coefficient alpha 0951greater than 0.6. Thus meaning that the question items for variable Perceived Ease (X1) is valid and reliable for further testing.

Table 2 - Validity and Reliability Variables Perceived usefulness (X2)

\begin{tabular}{|c|c|c|c|c|}
\hline \multirow{2}{*}{ Group } & \multirow{2}{*}{ Item number } & \multicolumn{2}{|c|}{ validity } & Coefficient \\
\hline & & Correlation (r) & Probability $(p)$ & Alpha \\
\hline \multirow{6}{*}{$\mathrm{X} 2$} & $\mathrm{X} 2.1$ & 0698 & 0000 & \multirow{6}{*}{0733} \\
\hline & $\mathrm{X} 2.2$ & 0493 & 0001 & \\
\hline & $\mathrm{X} 2.3$ & 0664 & 0000 & \\
\hline & $\times 2.4$ & 0824 & 0000 & \\
\hline & $\times 2.5$ & 0689 & 0000 & \\
\hline & X2.6 & 0655 & 0000 & \\
\hline
\end{tabular}

Based on data from the above table shows all the items of questions for the variable has a value perception of the usefulness of the probability of less than 0.05 and has a 
coefficient alpha 0733greater than 0.6. Thus, it means that the item Perceived Usefulness questions to variable (X2) valid and reliable for further testing.

Table 3 - Validity and Reliability Variable Uses E-Budgeting System (Y)

\begin{tabular}{|c|c|c|c|c|}
\hline \multirow{2}{*}{ Group } & \multirow{2}{*}{ Item number } & \multicolumn{2}{|c|}{ validity } & \multirow{2}{*}{$\begin{array}{c}\text { Coefficient } \\
\text { Alpha }\end{array}$} \\
\hline & & Correlation (r) & Probability $(p)$ & \\
\hline \multirow{10}{*}{$\mathrm{Y}$} & $\mathrm{Y1}$ & 0887 & 0000 & \multirow{10}{*}{0918} \\
\hline & Y2 & 0546 & 0000 & \\
\hline & Y3 & 0866 & 0000 & \\
\hline & Y4 & 0832 & 0000 & \\
\hline & Y5 & 0664 & 0000 & \\
\hline & Y6 & 0811 & 0000 & \\
\hline & Y7 & 0831 & 0000 & \\
\hline & Y8 & 0413 & 0000 & \\
\hline & Y9 & 0853 & 0000 & \\
\hline & $\mathrm{Y} 10$ & 0622 & 0000 & \\
\hline
\end{tabular}

Based on data from the above table shows all the items of questions for variable use in the use of E-Budgeting has a probability value less than 0.05 and has a coefficient alpha 0918greater than 0.6. Thus meaning that the question items for variable E-Budgeting (X3) valid and reliable for further testing.

Based on the median, modes, and median, descriptively indicate that respondents gave a good response to the importance of the quality system, and the quality of information is a predictor of user satisfaction. Respondents also gave a good response to the usability and feeling satisfied with the information systems was implemented. It is seen from the respondents' answers -rata average response indicators agree on the question that has been given by researchers.

Regression Model Analysis Calculation Results. The results of the regression tests performed in this study, the results are as follows:

Table 4 - Results of Multiple Linear Regression

\begin{tabular}{|c|c|c|}
\hline \multirow{2}{*}{ Variables } & \multicolumn{2}{|c|}{ Coefficients unstandardized } \\
\cline { 2 - 3 } & B & Std. Error \\
\hline (Constant) & 6718 & 4802 \\
\hline Perceived Ease to Use & 0139 & 0077 \\
\hline Perceived usefullnes & 1,188 & 0177 \\
\hline
\end{tabular}

Whereas, for the regression equation which has been built in this study are as follows:

$$
P S=\alpha+\mathrm{b}_{1} \cdot P E U+\mathrm{b}_{2} \cdot P U+\varepsilon
$$

Based on the results of the regression test with values that have been presented in the table above and refer to the equation that has been built in this study, the regression equation becomes:

$$
P S=6.718+.139 . P E U+1.188 . P U+\varepsilon
$$

Based on the above formulation, it can be seen that the constant value of variable EBudgeting System Usage amounted 6718, In this study the interpretation on the use of EBudgeting System at the time of $\mathrm{x} 1$ (Perceived Ease to Use E-Budgeting) $=0$ and $\mathrm{x} 2$ (Perceived usefulness E-Budgeting) $=0$, then the usage of E-Budgeting System will also tend to rise by6718, When there is an increase in the variable perceived ease to use of one unit and variable Perceived usefulness is constant, then the variable will be increased by 0.139 . When variable perceived usefulness an increase of one unit and variable Perceived Ease to Use E-Budgeting is constant, then the variable will be increased by 1,188.

The results presented above also show that the direction of the relationship that both the independent variable on the dependent variable is known to have a direct relationship. It 
is clear that if the Perceived Ease to Use and Perceived usefulness produced by EBudgeting ride the use of E-Budgeting System will also rise.

Proving hypothesis:

Test $F$ or simultaneous test. Based on the results of the $F$ test (simultaneous) which has been conducted by researchers, the results are as follows:

Table 5 - F Test Results

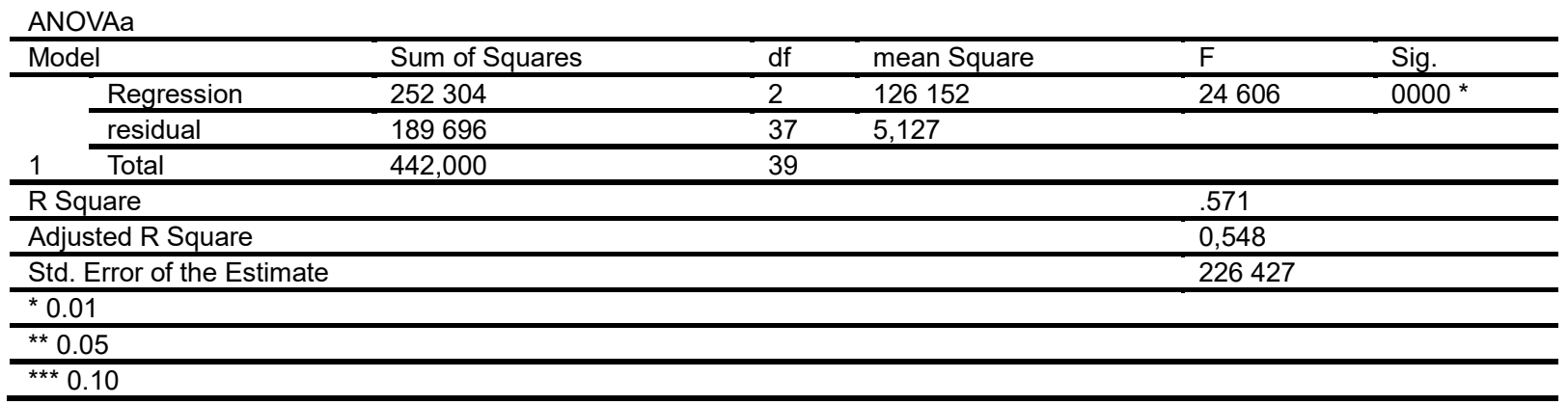

Based on the above table, it can be seen that the value of $\mathrm{F}$ obtained in this study was 24606 with significance level was 0.000. As for the value of $F$ table obtained amounted4.0982, So it can be seen that in this study Fhitung > Ftabel and sig smaller than the probability value of 0.05 , or a value $0.000<0.05$, which means that the independent variable in this study consisted of perceived ease to use and perceived usefulness proven effect simultaneous to the dependent variable in this case the use of E-Budgeting. From the table above magnitude adjusted R2 is.571, This means $57.1 \%$ Variation of the use of eBudgeting can be explained by the variation of the two independent variables. While the rest $(100 \%-57.1 \%=42,9 \%)$ is explained by other causes outside the model.

$T$ test or partial test. Based on the results of the $t$ test (partial) which has been conducted by researchers, the results are as follows:

Table 6 - T Test Results

\begin{tabular}{ccccc}
\hline variables & $\mathrm{t}$ & Sig. & $\mathrm{t}$ table & Information \\
\hline (Constant) & 1,399 & 0170 & & \\
\hline Perceived Ease to Use & 1,808 & 0079 & 202439 & H1 is rejected \\
\hline perceived usefullness & 6,691 & 0000 & 202439 & H2 received \\
\hline
\end{tabular}

Based on the presentation of data in the table above, it is known that there is one variable that has a value of $t$ greater than $t$ table and sig smaller than the probability value of 0.05 , or a value $0.000<0.05$, which means that the variable Perceived usefullness otherwise affect the user satisfaction.

\section{RESULTS AND DISCUSSION}

In an effort to optimize the implementation of accountability and transparency in government budgeting technological developments as an instrument of public disclosure of the budget, namely e-budgeting, which is one component in e-government. The use of information technology to promote accountability and public transparency, the better. In addition to the electronic transparency of the budget, the public is expected to be more active to participate in the area of financial supervision.

The indicators can be used as a tool to measure the implementation of accountability according to the State Administration Institute (2007: 57) is: a). Issued accountable budget management; b). Accountability for performance; c). The intensity of divergence; d). followup of irregularities. Budget transparency refers to the extent to which the public can obtain information on the financial activities of the government and its implications (Andrianto, 2007: 21). Budget transparency can be measured by several aspects, in addition to ease of 
access to information, mechanisms and public access in the delivery of the opinion should also be considered. Openness referring to the opening of opportunities for citizens to submit comments and criticism of the government is judged not transparent (Widodo, 2001: 28).

Accountability and transparency in financial management through the desired ebudgeting will go smoothly, budget accountability and local government activities can also be known by the public and interested parties. Perception of individual users of e-budgeting indeed affects successful application. According to testing for perceived usefulness This concurs with the model Davis (1989), but the results are different from the results for the variable of perceived ease to use, based on the results of the comparison between $t$ arithmetic with $t$ table that has been presented above, it can be seen that in partial perceived ease to use proved to have no effect on the utilization of E-Budgeting, it can be analyzed that the implementation of e-budgeting in East Java Governmental is mandatory (compulsory) so that the user's perception of the system may not work .

Perceived ease to use no positive effect on the use of E-Budgeting can be caused by E-Budgeting system this is mandatory or compulsory. Perception is easy or difficult the operation of this app in the end users still has to use it in the budgeting process. For others the lack of knowledge of the users in applying E-Budgeting, this can be an input for the authorities on the implementation of the E-Budgeting is to continue to conduct evaluations of the system and continue to provide the missing technical training related to E-Budgeting.

Perceived usefulness positive effect on the use of E-Budgeting accordance Davis study (1989) showed that perceived usefulness significant effect on the use of E-Budgeting. The positive effects are caused because most users E-Budgeting can facilitate local government / Budget Team Local Government in the budgeting process, the budgeting process transparent budgeting process is fast, effective and efficient, the budget in accordance with the needs of the activities, chronological clear budgets and reports according to the needs can be met easily thus improving the quality of the budget in terms of compliance with document planning, accuracy and accountability value and account spending allocations. Thus the importance of the perceived benefits of the users eBudgeting, then it is certain that this system should continue to be used and improved in terms of both content and reports generated in terms of ease of use. Simultaneously perception of convenience and perceived benefits of e-Budgeting by the user to the application of e-budgeting is something that is very important for the transparency of budget management, with a good perception will lead to a commitment for its users to continue to make improvements in order to realize the implementation of public service excellence.

\section{CONCLUSION}

This study aimed to carry out partial testing of the TAM model in the use of EBudgeting in terms of perceived ease to use and perceived its usefulness in East Java Provincial Government is expected to summarize the process of budgeting.. This study data analysis using multiple linear regression. This study has met the classical assumption, covering multicollinearity test, autocorrelation test, heteroscedasticity test, and test for normality,

The conclusion from this study is that $\mathrm{H} 1$ : Perceived ease to use has a positive effect on the use of E-Budgeting is not proven / rejected. Results of statistical analysis showed that perceived ease to use does not affect the utilization of E-Budgeting System. These results do not support the results Davis (1989) that the higher the perceived ease to use, the higher is also the utilization of the system. For $\mathrm{H} 2$ is perceived usefulness positive effect on the utilization of the system E-Budgeting proven / accepted. These results support the results Davis (1989) which states that the higher the perceived usefulness positively related to the utilization of E-Budgeting System. But simultaneously perceived ease to use and perceived usefulness of proven effect on the utilization of the system E-Budgeting. With the results of these hypotheses can be underlined that the perception of ease in the use of e-budgeting is still lacking, it is caused by a lack of the ability of individuals and therefore important to 
improve the user's knowledge as to the benefits of the system is excellent in supporting government transparency.

\section{LIMITATIONS OF RESEARCH}

Implementation of E-Budgeting in East Java Province Government just done a study of variables perceived ease to use and perceived usefullness. For further research in order to discuss about the research with menambahan theory UTAUT and the addition of other variables can produce research that will provide scientific information is more complete, indepth and tested that will ultimately be able to contribute in the creation of bureaucratic reforms for good governance that promotes excellent service for the welfare of the community.

\section{REFERENCES}

1. Alcaraz-Quiles, FJ, Navarro-Galera, A., \& Ortiz-Rodríguez, D. (2014). Factors Influencing the transparency of sustainability information in the regional Governments: an empirical study. Journal of Cleaner Production, 82 (Supplement C), 179-191.

2. Andrianto, Nico. 2007. Good e-Government: Transparency and Public Accountability Through e-Government. Ayumedia Publishing. Members IKAPI Java: Malang. Davis, FD 1989. Perceived Usefulness, Perceived Ease of Use and Acceptance of Information Systems Technology. MIS Quartery, Vol. 13, No. 3, h.319-339.

3. Chen, Y., \& Lin, Y. (2012). Analysis of the Impact of Government Information Operation on Emergency Management Information System Application. Procedia Engineering, 29

4. Choi, H., (2016). Rethinking the assessment of e-government implementation in developing countries from the perspective of the design-reality gap: Applications in the Indonesian e-procurement system. Telecommunications Policy, 40 (7), 644-660.

5. Gao, X., \& Lee, J. (2017). E-government services and social media adoption: Experience of small local Governments in Nebraska State. Government Information Quarterly.

6. Igbaria, M., 1994. Work Experience, Job Involvement, and Quality of Work Life among Information Systems Personnel. MIS Quarterly, June, h.175-201.

7. Mardiasmo. 2002. Autonomy and Regional Financial Management. Yogyakarta.

8. World Bank: 2001. Definition of E-Government. December 12.

9. Widodo Joko. Good Governance 2001. The study of Dimensions: Accountability and control of bureaucracy In the Era of Decentralization and Regional Autonomy. Surabaya: Insan Scholar.

10. Rahardjo, Budi. 2000. Implications of Information Technology and the Internet to Education, Business, and Government: Ready Indonesia? Available: http://www.cert.or.id

11. E-Budgeting System. Flow 2017. Budgetary Surabaya City Government (https://ebudgeting.surabaya.go.id/new_portal/ accessed on May 15, 2018)

12. Venkatesh, V and FD Davis. 1996. "A Model of the Antecendents of Perceived Ease of Use = Development and Test", Decision Science Vol. 27, 481 h.451-.

13. Alcaraz-Quiles, FJ, (2014). Factors influencing the transparency of sustainability information in the regional Governments: an empirical study. Journal of Cleaner Production, 82 (Supplement C), 179-191.

14. Chen, Y., \& Lin, Y. (2012). Analysis of the Impact of Government Information Operation on Emergency Management Information System Application. Procedia Engineering, 29 (Supplement C), 3023-3027. doi: https://doi.org/10.1016/j.proeng.2012.01.433

15. Choi, H., (2016). Rethinking the assessment of e-government implementation in developing countries from the perspective of the design-reality gap: Applications in the Indonesian e-procurement system. Telecommunications Policy, 40 (7), 644-660.

16. Gao, X., \& Lee, J. (2017). E-government services and social media adoption: Experience of small local Governments in Nebraska State. Government Information Quarterly. doi: https://doi.org/10.1016/j.giq.2017.09.005 